\title{
SPATIO-TEMPORAL VARIATIONS IN ZOOPLANKTON COMMUNITY STRUCTURE AND WATER QUALITY IN A CHINESE EUTROPHIC RIVER
}

\author{
WU, L. ${ }^{1 *}-$ ZHOU, M. ${ }^{1}-$ SHEN, Z. ${ }^{1}-$ CUI, Y. ${ }^{2}-$ FENG, W. ${ }^{2 *}$ \\ ${ }^{1}$ School of Life Science, Hefei Normal University \\ Hefei 230601, China. \\ (phone: +86-551-6367-4150; fax: +86-551-6367-4150) \\ ${ }^{2}$ Institute of Hydrobiology, Chinese Academy of Sciences \\ Wuhan 430072, China \\ (phone: +86-27-6878-0009; fax: +86-27-6878-0009) \\ *Corresponding authors \\ e-mail:wuli090121@126.com; fengweisong@ihb.ac.cn \\ (Received $19^{\text {th }}$ Oct 2016; accepted $27^{\text {th }}$ Apr 2017)
}

\begin{abstract}
To collect information about the community structure of zooplankton and to study how zooplankton respond to environmental conditions, zooplankton samples were collected from seven stations in a heavily polluted river (the Nanfei River, China). Samples were collected in March (spring) and June (summer) 2014, September (autumn) and December (winter) 2013. A total of 275 species of zooplankton belonging to 79 genera were identified, the total zooplankton abundance was $193040 \mathrm{ind}$./L. Protozoa and rotifer comprised a high proportion of species number and abundance of zooplankton. The upper reaches had higher greater species number and lower abundance than those in middle and lower reaches, and at the entrance of Chaohu Lake. The species number and abundance of zooplankton were the highest in autumn, and the lowest in winter. The habitats of Nanfei River had high spatiotemporal heterogeneity, revealed by unweighted pair-group method using arithmetic averages (UPGMA) clustering analyses on environmental factors and detrended correspondence analysis (DCA) clustering analyses on zooplankton abundance. In addition, water quality of upper reaches was better than the middle and lower reaches, and the entrance; and better in autumn than in other three seasons in terms of species number, abundance, Shannon-Wiener index, and Pielou evenness index. Results of canonical correspondence analysis (CCA) indicate that the combination of water temperature, total phosphorus, total nitrogen, $\mathrm{pH}$, chemical oxygen demanded, soluble phosphate, and conductance rate were responsible for the variations in zooplankton community structure. Results of the present study indicated that zooplankton communities of the Nanfei River had obvious spatial and temporal heterogeneity, and the environmental factors played an important role in the changes in zooplankton community in Nanfei River.
\end{abstract}

Keywords: taxonomic richness; density; environmental factors; heterogeneity; urban river

\section{Introduction}

Being a key carrier of resources in natural environment, a river plays an important role in making an urban landscape during the formation and development of the city. With the continued expansion of cities worldwide and the constant intervention of human activities, a huge amount of anthropogenic pollutants have been discharged into urban rivers, causing serious environmental problems, such as deterioration of water quality, landscape destruction, decline in biodiversity, and so on (Swaney et al., 2012). Urban river pollution is fast becoming an issue of greater importance in water management throughout the world (Shah and Tachamo, 2009; Yu et al., 2014). 
Restoration and maintenance of the urban river health is a common goal of urban river management in countries all over the world (Deng et al., 2014; Song and Yang, 2002).

As an important link in the transformation of energy from producers to consumers, free-living zooplanktonic organisms are a fundamental component of aquatic ecosystems (Sharma et al., 2010; Sousa et al., 2008). Zooplanktonic organisms are bioindicators of water quality because of their growth and distribution are closely correlated to ecological environmental parameters (Ergönül et al., 2016; Lin et al., 2014; Roman et al., 2012; Sellami et al., 2010; Vincent et al., 2012). The zooplankton communities are often used as important tools to detect the changes in water quality and assess the health of rural water bodies (Dorak, 2013; Gaygusuz and Dorak, 2013; Ning et al., 2013; Reckendorfer et al., 1999; Wu et al., 2008). However, it should be noted that the zooplankton of urban rivers and urban river environments have received relatively little attention (de Paggi and Devercelli, 2011; Yu et al., 2014).

The Nanfei River is one of important urban rivers of Hefei City, which has a population of over 7790000 people. With the rapid economic development and urban population expansion, the industrial wastewater and domestic sewage from factories and residences around the rivers was directly or indirectly discharged into the water bodies, and some pollutants accumulated in the water, and it is one of the numerous rivers in China, which has been heavily polluted. Therefore, in the government- initiated pollution treatment programs of the Chaohu Lake drainage area, as one of the most important inflow rivers of Chaohu Lake, the Nanfei River has garnered more attention from the public and the government (Li et al., 2014b; Zhang et al., 2014). However, there is lacking of systematic investigation of zooplankton community structure in the Nanfei River.

The aim of this study was to examine the spatial and temporal changes in zooplankton communities taking place in the Nanfei River, and to identified critical factors affecting dynamics of zooplankton community structure, and to provided a monitoring tool to improve water quality of the Nanfei River for future studies.

\section{Materials and Methods}

\section{Study area}

The Nanfei River $\left(31^{\circ} 39^{\prime} \sim 31^{\circ} 58^{\prime} \mathrm{N}, 117^{\circ} 08^{\prime} \sim 117^{\circ} 27^{\prime} \mathrm{E}\right)$, flowing through Hefei City in southeast China, is $70 \mathrm{~km}$ long, has a watershed of $1446 \mathrm{~km}^{2}$ and channel widths between 20 and $150 \mathrm{~m}$, and drains into Chaohu Lake, one of the five biggest freshwater lakes in China (Zhang et al., 2014). Climate of the Nanfei River is subtropical monsoon. In present study, seven stations were chosen from the Nanfei River. Station S1 $\left(31^{\circ} 54^{\prime} 53.61^{\prime \prime} \mathrm{N}, 117^{\circ} 06^{\prime} 26.42^{\prime \prime} \mathrm{E}\right)$ and station S2 $\left(31^{\circ} 53^{\prime} 02.46^{\prime \prime} \mathrm{N}, 117^{\circ} 12^{\prime} 53.86^{\prime \prime} \mathrm{E}\right)$ were set in the upper reaches located in Xiaochangying to Dongpu Reservoir, the surrounding regions of the upper reaches are mainly dominated by farmland. Station Z1 $\left(31^{\circ} 52^{\prime} 39.71^{\prime \prime} \mathrm{N}, 117^{\circ} 16^{\prime} 24.93^{\prime \prime} \mathrm{E}\right)$ and station Z2 $\left(31^{\circ} 50^{\prime} 55.72^{\prime \prime} \mathrm{N}, 117^{\circ} 18^{\prime} 39.63^{\prime \prime} \mathrm{E}\right)$ in the middle reaches located in Mengchenglu Bridge to Tonglinglu Bridge, this area of Nanfei River goes through the Hefei City. Station X1 (31 $\left.{ }^{\circ} 48^{\prime} 20.64^{\prime \prime} \mathrm{N}, 117^{\circ} 22^{\prime} 53.81^{\prime \prime} \mathrm{E}\right)$ and station X2 $\left(31^{\circ} 46^{\prime} 19.78^{\prime \prime} \mathrm{N}, 117^{\circ} 25^{\prime} 34.83^{\prime \prime} \mathrm{E}\right)$ in the lower reaches located in Guanzhenying to Liu xiaodun, with docks, warehouses, factories on both sides of the river. Station $\mathrm{R}$ $\left(31^{\circ} 42^{\prime} 25.70^{\prime \prime} \mathrm{N}, 117^{\circ} 24^{\prime} 23.38^{\prime \prime} \mathrm{E}\right)$ in the entrance located in Shikou, where phenomenon of beach reclamation and dumping waste is widespread on both sides of the river (Fig. 1). 
Samples were collected in four seasons: September 2013 (autumn), December 2013 (winter), March 2014 (spring), and June 2014 (summer). In each season, seven stations were sampled within 1 day.

\section{Sample collection}

Samples for qualitative identification of zooplankton were collected at the water surface with a No. 25 plankton net $(64 \mu \mathrm{m})$ and preserved immediately with formaldehyde (Zhang and Huang, 1991). Integrated water samples for abundance enumerating were taken with a glass water sampler from the water surface to the bottom at one-meter intervals, and preserved immediately with acid Lugol solution (Wu et al., 2008). Simultaneously, one liter of water was collected at each station for chemical characterization (Huang, 2000).

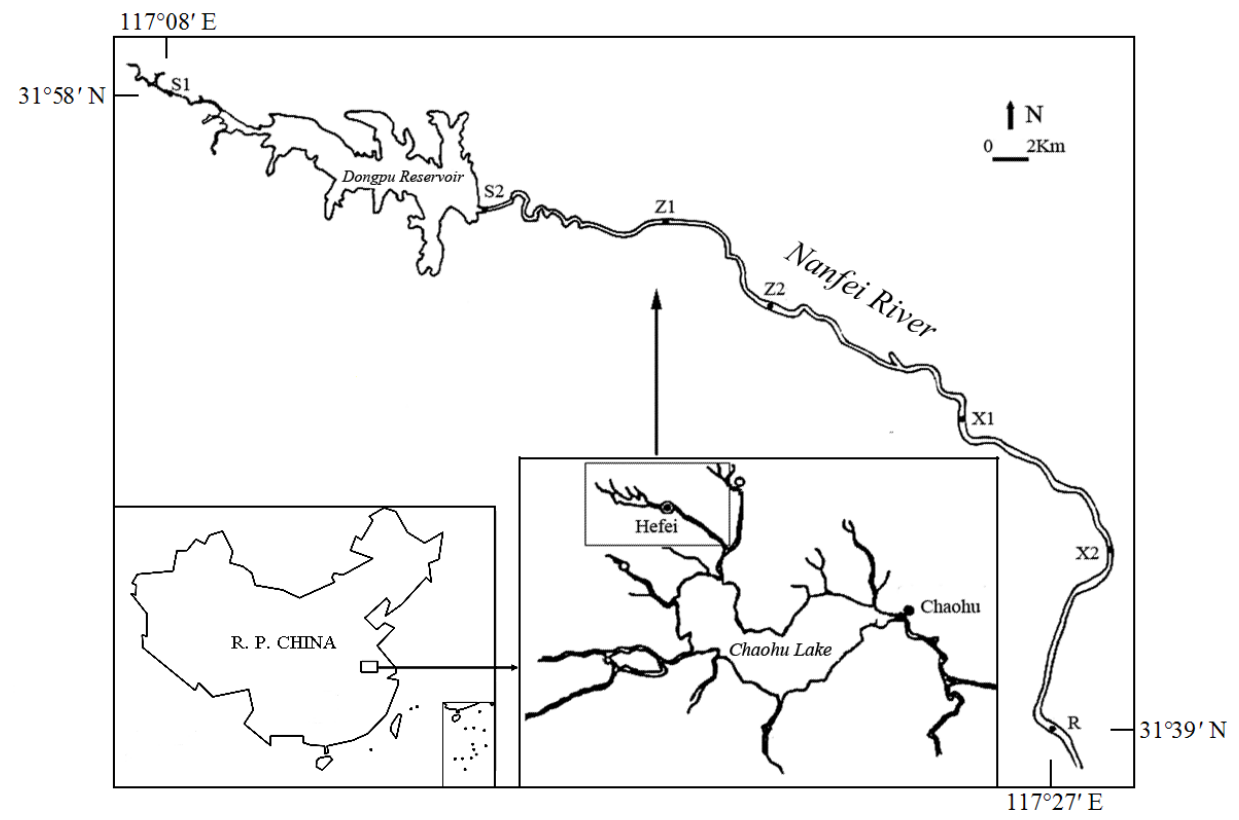

Figure 1. Sampling stations of zooplankton in Nanfei River

\section{Physicochemical and morphological analysis}

Water temperature was determined in the field simultaneously with zooplankton collection. One liter of water was collected to measure $\mathrm{pH}$, total phosphorus (TP), total nitrogen (TN), conductivity (EC), chemical oxygen demand (COD), nitrate $\left(\mathrm{NO}_{3}-\mathrm{N}\right)$, ammonia nitrogen $\left(\mathrm{NH}_{4}-\mathrm{N}\right)$ and soluble phosphorus (SP). All of these physicochemical factors were measured according to standard methods (Huang, 2000).

Zooplanktonic organisms were identified under an Axioplan 2 Imaging microscope (Zeiss, Jena, Germany) according to Shen et al. (1990), Wang (1961), Zhang and Huang (1991). The sedimentation method described by Zhang and Huang (1991) was used for protozoa and rotifer abundance enumerating, and triplicate counts were made for each sample. Quantitative samples of crustacean were collected by filtering $20 \mathrm{~L}$ water samples through a No. 25 plankton net and preserved with 5\% formalin. Counting was undertaken in the laboratory using a compound microscope (at a magnification of $100 \times$ ). The whole filtered sample was used for counting crustacean. 


\section{Data analysis}

For each zooplankton sample, the Shannon-Wiener diversity index $\left(H^{\prime}\right)$ (Shannon and Weaver, 1949) and species evenness index $(J)$ (Pielou, 1966) were calculated according to the following equation:

$$
\begin{gathered}
H^{\prime}=-\sum_{i=1}^{S} P_{i} \log _{2} P_{i} \\
J=H^{\prime} / \log _{2} S
\end{gathered}
$$

where $H^{\prime}$ is the Shannon-Wiener diversity index, $J$ is the species evenness index, $S$ is the number of species, $P_{i}$ is the relative abundance of each species.

\section{Statistical analysis}

Based on environmental factors, the unweighted pair-group method using arithmetic averages (UPGMA) clustering was used to investigate the similarity among the seven stations. The data of environmental factors were $\log (1+\mathrm{x})$ transformed before UPGMA to improve the normal distribution approximation. Euclidean distance was used for the UPGMA analysis of environmental factors. UPGMA was performed using the software program XLSTAT-Pro 2015.

Detrended correspondence analysis (DCA) and canonical correspondence analysis (CCA) were performed in CANOCO 4.5 to explore the distribution of zooplankton community in relation to environmental factors and sampling stations. Species whose occurrence frequency and relative abundance were less than $25 \%$ and $0.1 \%$ were arbitrarily excluded from the CCA analysis.

\section{Results}

\section{Environmental parameters}

Physicochemical characterizations of four seasons and seven stations were summarized in Table 1. Concentrations of TP, TN, $\mathrm{NH}_{4}-\mathrm{N}, \mathrm{NO}_{3}-\mathrm{N}$, and COD in winter were greater than other seasons, EC and concentration of SP exhibited maxima in spring. In general, the trophic level of the river water in winter was higher than other seasons. Except $\mathrm{pH}$, other eight physicochemical factors of Z1, Z2, X1, X2 were higher than S1, S2, R. In general, the trophic level of the river water in the middle and lower reaches were higher than the upper reaches and the entrance. Significant differences between seasons or stations (ANOVA, $P<0.05$ ) were found in the concentrations of TP, TN, $\mathrm{COD}$, and SP. WT, $\mathrm{pH}$, and EC were also significantly different between sampling seasons or stations (ANOVA, $P<0.05$ ). The UPGMA clustering showed that samples within a season were generally clustered into the same group (Fig. 2a), and environmental conditions of station $\mathrm{Z} 1, \mathrm{Z} 2, \mathrm{X} 1$, and X2 were first grouped into a cluster, and then grouped together with station $\mathrm{R}$; stations $\mathrm{S} 1$ and $\mathrm{S} 2$ were divided into one groups (Fig. 2b). 
Table 1. Comparison of physicochemical characteristics $(M e a n+S D)$ within-season and within-station in Nanfei River

\begin{tabular}{|c|c|c|c|c|c|c|c|c|c|c|c|c|c|c|c|c|c|c|c|c|c|c|c|c|}
\hline & \multicolumn{2}{|l|}{ Spring } & \multicolumn{2}{|c|}{ Summer } & \multicolumn{2}{|c|}{ Autumn } & \multicolumn{2}{|c|}{ Winter } & \multicolumn{3}{|c|}{ S1 } & \multicolumn{2}{|l|}{$\mathrm{S} 2$} & \multicolumn{2}{|l|}{$\mathrm{Z} 1$} & \multicolumn{2}{|l|}{$\mathrm{Z} 2$} & \multicolumn{2}{|l|}{$\mathrm{X} 1$} & \multicolumn{2}{|l|}{$\mathrm{X} 2$} & \multicolumn{3}{|l|}{$\mathrm{R}$} \\
\hline & Mean & $\mathrm{SD}$ & Mean & $\mathrm{SD}$ & Mean & $\mathrm{SD}$ & Mean & SD & $P$ & Mean & SD & Mean & $\mathrm{SD}$ & Mean & $\mathrm{SD}$ & Mean & SD & Mean & $\mathrm{SD}$ & Mean & SD & Mean & $\mathrm{SD}$ & $P$ \\
\hline WT $\left({ }^{\circ} \mathrm{C}\right)$ & 17.10 & 1.40 & 28.20 & 2.20 & 24.60 & 1.60 & 6.90 & 2.70 & 0.00 & 16.70 & 10.40 & 18.80 & 9.60 & 19.50 & 8.60 & 21.40 & 9.00 & 20.70 & 9.50 & 20.10 & 9.80 & 17.20 & 9.40 & 0.01 \\
\hline $\mathrm{pH}$ & 7.68 & 0.37 & 8.02 & 0.09 & 7.59 & 0.53 & 7.75 & 0.21 & 0.01 & 7.73 & 0.20 & 8.23 & 0.32 & 7.59 & 0.29 & 7.51 & 0.28 & 7.65 & 0.37 & 7.65 & 0.46 & 7.98 & 0.14 & 0.00 \\
\hline $\mathrm{TP}(\mathrm{mg} / \mathrm{L})$ & 0.59 & 0.50 & 0.47 & 0.44 & 0.62 & 0.50 & 0.63 & 0.59 & 0.00 & 0.19 & 0.12 & 0.07 & 0.02 & 0.56 & 0.41 & 1.05 & 0.50 & 0.80 & 0.45 & 0.96 & 0.39 & 0.40 & 0.41 & 0.00 \\
\hline $\mathrm{TN}(\mathrm{mg} / \mathrm{L})$ & 9.27 & 5.96 & 8.39 & 6.23 & 8.14 & 7.22 & 12.61 & 8.42 & 0.00 & 3.75 & 4.75 & 1.08 & 0.52 & 10.51 & 6.92 & 15.38 & 1.64 & 13.89 & 3.67 & 15.52 & 3.14 & 7.11 & 7.76 & 0.00 \\
\hline $\mathrm{NH}_{4}-\mathrm{N}(\mathrm{mg} / \mathrm{L})$ & 3.53 & 2.30 & 0.25 & 0.12 & 3.56 & 3.48 & 4.33 & 3.33 & N.S. & 0.96 & 1.75 & 0.08 & 0.06 & 2.71 & 3.03 & 4.62 & 3.02 & 4.80 & 3.14 & 5.36 & 3.64 & 1.90 & 3.06 & N.S. \\
\hline $\mathrm{NO}_{3}-\mathrm{N}(\mathrm{mg} / \mathrm{L})$ & 1.41 & 1.17 & 0.58 & 0.22 & 2.92 & 3.11 & 4.89 & 3.46 & N.S. & 1.94 & 1.99 & 0.59 & 0.31 & 2.60 & 4.28 & 4.00 & 4.56 & 2.47 & 2.78 & 2.97 & 1.76 & 2.61 & 2.96 & N.S. \\
\hline $\mathrm{COD}(\mathrm{mg} / \mathrm{L})$ & 9.77 & 4.69 & 13.53 & 1.65 & 12.53 & 5.78 & 24.20 & 40.22 & 0.00 & 7.52 & 4.38 & 7.53 & 3.34 & 12.14 & 2.07 & 16.36 & 3.15 & 13.44 & 1.92 & 39.22 & 50.67 & 8.85 & 4.36 & 0.01 \\
\hline $\mathrm{SP}(\mathrm{mg} / \mathrm{L})$ & 0.42 & 0.46 & 0.06 & 0.03 & 0.41 & 0.45 & 0.37 & 0.40 & 0.02 & 0.09 & 0.11 & 0.02 & 0.01 & 0.39 & 0.43 & 0.65 & 0.55 & 0.51 & 0.52 & 0.38 & 0.31 & 0.15 & 0.23 & 0.00 \\
\hline $\mathrm{EC}(\mathrm{us} / \mathrm{cm})$ & 528 & 259 & 373 & 56 & 447 & 235 & 333 & 114 & 0.00 & 220 & 115 & 229 & 108 & 526 & 177 & 488 & 238 & 487 & 144 & 566 & 190 & 426 & 39 & 0.00 \\
\hline
\end{tabular}

$P$, level of significance (ANOVA, $P<0.05$ ) between seasons or stations; N.S., not significant. 


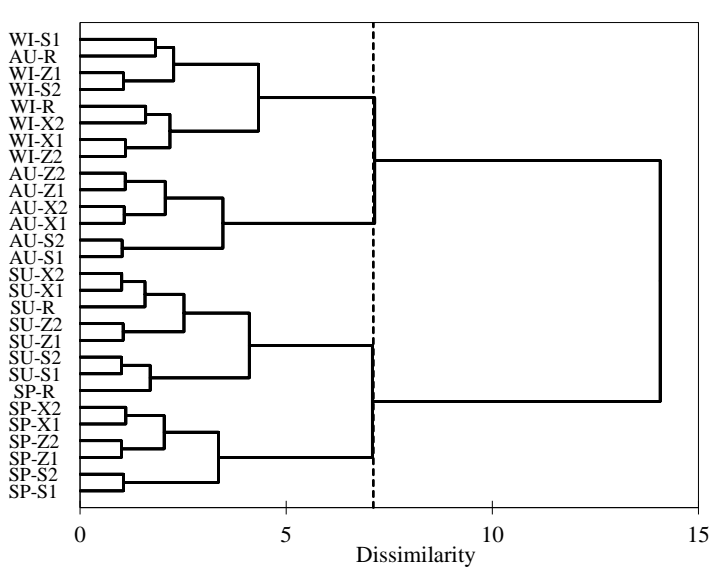

(a)

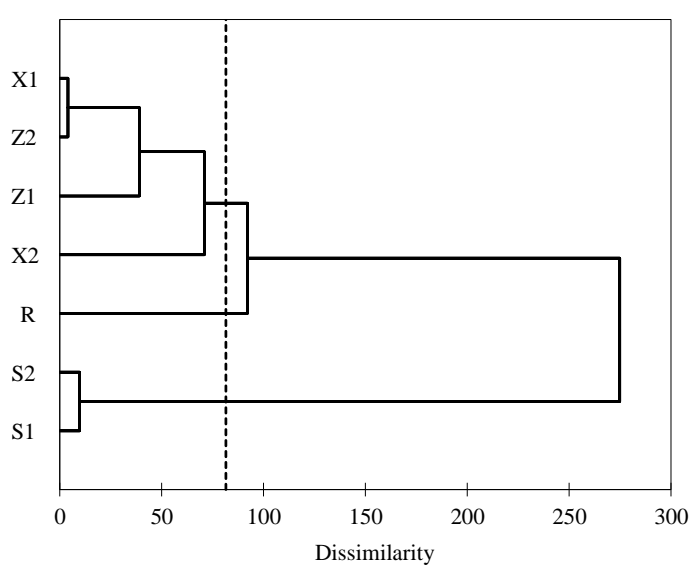

(b)

Figure 2. Group relationships of seven sampling stations. UPGMA clustering on the basis of the physicochemical characteristics of each station (a) and average value of each station (b).

\section{Zooplankton community structure}

A total of 275 species of zooplankton belonging to 79 genera were identified. Among all the taxa, protozoans (116 species) and rotifers (127 species) were the dominant groups, contributing $42.2 \%$ and $46.2 \%$ of total taxa number, respectively. Only 23 taxa $(8.3 \%)$ of cladocera and 9 taxa (3.3\%) of copepoda were found (Appendix). In terms of each station, species number of station S1, S2, Z1, Z2 were higher than station X1, X2, $\mathrm{R}$ (Fig. 3a). In terms of each season, species number was highest in autumn (154 species), followed by summer (129 species), spring (96 species), and winter ( 87 species) (Fig. 3b). Ceratium cornutum, Euglena gasterosteus, Euglena oxyuris, Paramecium caudatum, Brachionus angularis, Brachionus calyciflorus, Brachionus urceus, Filinia longiseta, Keratella cochleari, Keratella valaa, Polyarthra trigla, Rotaria neptunia, Bosmina longirostris, Daphnia pulex, Daphniopsis tibetana, and Thermocyclops taihokuensis appeared in four seasons, and all of them occurred in high-nutrient conditions. The total zooplankton abundance was 193040 ind. /L (Fig. 3), protozoans and rotifers were the dominant groups, contributing $67.7 \%$ and $29.2 \%$ of total abundance, respectively. Cladocera and copepoda contributed $1.9 \%$ and $1.2 \%$ of total abundance, respectively. In terms of each station, zooplankton abundance of the stations $\mathrm{Z} 2$, X1and X2 were higher than the stations S1, S2, Z1 and R (Fig. 3a). In general, comparing with the middle and lower reaches, and the entrance, the upper reaches had higher species number and lower abundance. In terms of each season, zooplankton abundance was characterized by a peak in autumn (103443 ind. /L), followed by summer (54887 ind. /L), spring (18730 ind. /L) and winter (15980 ind. /L) (Fig. 3b). 


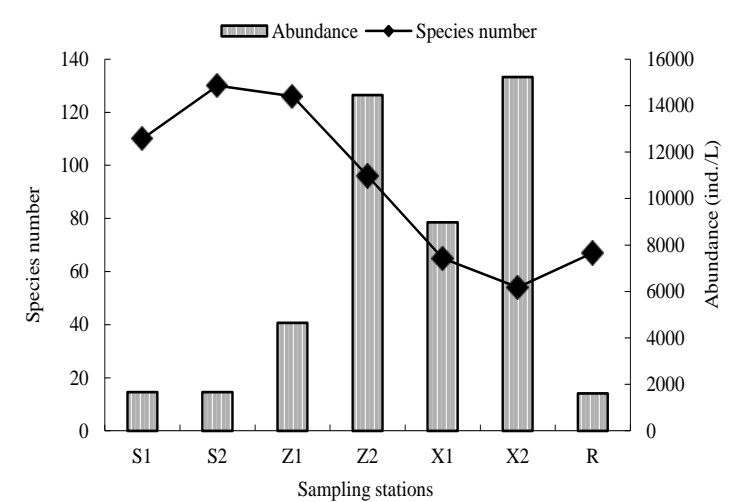

(a)

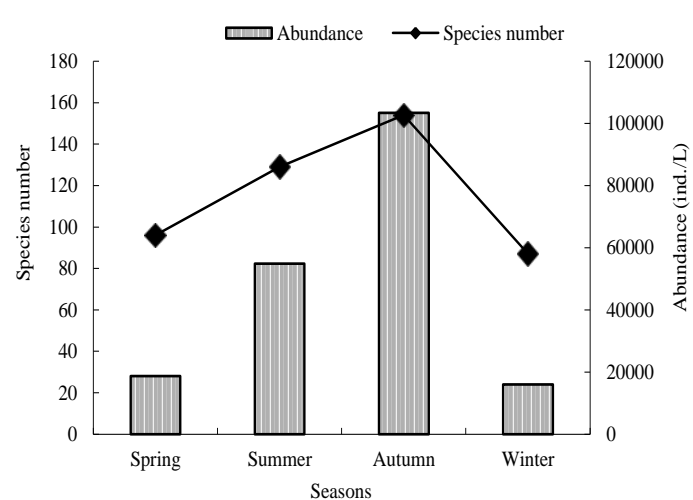

(b)

Figure 3. Species number and abundance of zooplankton in different stations (a) and seasons (b) in Nanfei River

\section{Dominant species of zooplankton}

Species whose occurrence frequency and relative abundance were more than $25 \%$ and $0.1 \%$, respectively, were the dominant species (Li et al., 2014a). Among 27 species of zooplankton, Ceratium cornutum, Difflugia glans, and Tintinnopsis wangi were generally as indicators of the clean water, others tended to have resistance to polluted water (Table 2). Paramecium caudatum, Brachionus calyciflorus, Brachionus urceus, Polyarthra trigla, Moina affinis appeared in each season, 11 dominant species appeared in three seasons. Summer and autumn had the highest number of dominant species (20 species), with Brachionus urceus as the most abundant species in these two seasons, and Epistylis sp. as the first dominant species in autumn. Spring had 17 species of dominant species, among which, Paramecium caudatum and Vorticella sp. were the first dominant species (5880 ind. /L). Winter had 16 species of dominant species, and Askenasia volvox was the first dominant species (8040 ind. /L).

Table 2. Abundance (ind. /L) of dominant species in different seasons in Nanfei River

\begin{tabular}{lcccc}
\hline Taxa & Spring & Summer & Autumn & Winter \\
\hline Ceratium cornutum & 60 & 210 & 270 & 0 \\
Euglena acus & 0 & 0 & 5880 & 0 \\
Euglena ehrenbergil & 0 & 540 & 1230 & 0 \\
Euglena gasterosteus & 930 & 90 & 5310 & 0 \\
Euglena geniculata & 690 & 0 & 600 & 0 \\
Euglena oxyuris & 30 & 19780 & 1290 & 0 \\
Euglena proxima & 0 & 420 & 240 & 0 \\
Phacus triqueter & 0 & 30 & 270 & 0 \\
Difflugia glans & 0 & 60 & 150 & 60 \\
Askenasia volvox & 0 & 0 & 0 & 8040 \\
Epistylis sp. & 0 & 30 & 40320 & 660 \\
Paramecium caudatum & 5880 & 330 & 240 & 2190 \\
Tintinnopsis wangi & 210 & 0 & 120 & 60
\end{tabular}




\begin{tabular}{lcccc} 
Vorticella campanula & 0 & 0 & 0 & 1320 \\
Vorticella sp. & 5880 & 0 & 0 & 0 \\
Brachionus angularis & 0 & 240 & 450 & 30 \\
Brachionus calyciflorus & 180 & 180 & 30 & 660 \\
Brachionus urceus & 30 & 18840 & 19830 & 60 \\
Filinia longiseta & 90 & 1560 & 690 & 0 \\
Keratella cochlearis & 120 & 240 & 0 & 120 \\
Keratella valaa & 60 & 540 & 150 & 90 \\
Hexarthra mira & 30 & 1620 & 0 & 0 \\
Polyarthra trigla & 150 & 2210 & 570 & 540 \\
Rotaria neptunia & 90 & 630 & 0 & 120 \\
Synchaeta pectindta & 0 & 150 & 0 & 180 \\
Daphnia magna & 233.1 & 0 & 0.05 & 0.1 \\
Moina affinis & 0.05 & 0.05 & 518.7 & 1.65 \\
Total taxa & 17 & 20 & 20 & 16 \\
\hline
\end{tabular}

\section{Shannon-Wiener index and Pielou evenness index of zooplankton}

According to Fig. 4a, diversity index of the stations S1 (2.59), S2 (3.22), and Z1 (2.83) were higher than the stations Z2 (1.69), X1 (2.49), X2 (2.23), and R (2.33). In general, diversity index of the upper reaches was higher than the middle and lower reaches, and the entrance. Diversity index of autumn (3.24) was higher than spring (2.21), summer (2.19), and winter (2.29) (Fig. 4b). The variation trend of Pielou evenness index was similar to diversity index in Nanfei River. According to Shen et al. (1990), station S2 and autumn were under slight pollution, and the other stations and seasons were under intermediate pollution. Water quality of upper reaches was better than the middle and lower reaches, and the entrance; and better in autumn than in other three seasons.

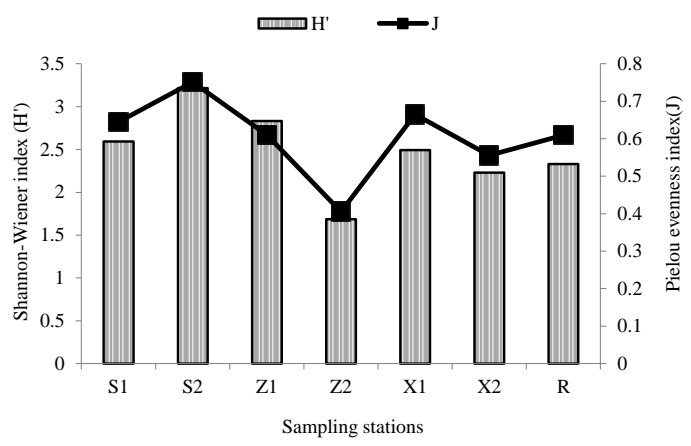

(a)

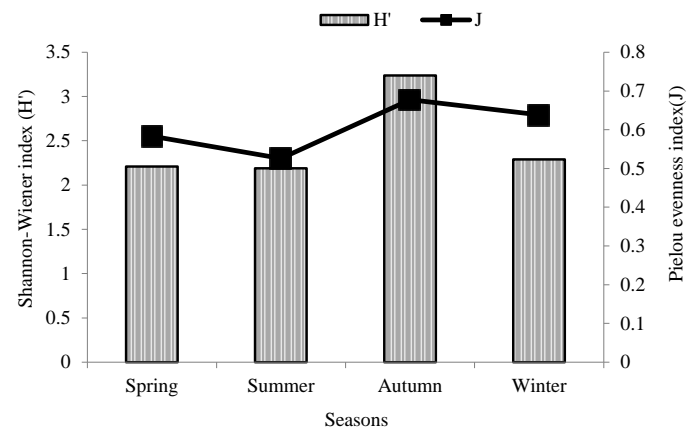

(b)

Figure 4. Shannon-Wiener index and Pielou evenness index of zooplankton in different stations (a) and seasons (b) in Nanfei River 


\section{Relationship between community structure and environment factors}

The results of DCA analysis showed that the sampling stations in four seasons were divided into four groups with the exception of several stations. Generally, the sampling stations in the same season were in the same group (Fig. 5a). Forward selection and Monte Carlo testing yielded a subset of water quality factors, including water temperature, TP, TN, $\mathrm{pH}, \mathrm{COD}, \mathrm{SP}$, and EC that significantly $(P<0.05)$ accounted for the variability in the species data. Temperature and TP were the most important factors related to zooplankton community in Nanfei River $(R=-0.69, R=0.72)$. The first three CCA axes explained $61.4 \%$ of the cumulative variance of the species-water quality relationship. The eigenvalues were 0.43 and 0.25 for the first and second axes, respectively. Species-environment correlations were relatively high for the first two ordination axes ( 0.95 and 0.87 , respectively) (Table 3$)$. Axis 1 was correlated primarily with temperature $(R=-0.69)$ and axis 2 was correlated primarily with TP, TN, and COD alkalinity ( $R=0.72, R=0.42, R=0.64$, respectively). For axis 3 , the best correlations were found with $\mathrm{pH}$, SP and $\mathrm{EC}(R=-0.55, R=0.67, R=0.55$, respectively). All seven of the water quality factors measured in this study, therefore, were correlated to some degree with zooplankton community composition in different seasons. In the biplots, $\mathrm{pH}$ and COD generally showed the strongest positive correlation with zooplankton community in spring and winter. TP, TN, SP and EC played an important role in the stations $\mathrm{Z} 2, \mathrm{X} 1$, and $\mathrm{X} 2$ in autumn and the station Z2 in summer, however, data from other stations in these two seasons were more highly correlated with temperature and $\mathrm{pH}($ Fig.5b).

The CCA ordination plots for environmental variables and species suggested that species occurrence was closely related to physicochemical conditions (Fig. 6). Euglena acus, Euglena ehrenbergil, Epistylis sp., Brachionus urceus, and Moina affinis were found to be more sensitive to TP, SP, EC and TN; Askenasia volvox and Brachionus calyciflorus were positively correlated with increasing COD, and negatively correlated with increasing water temperature; other species appear below the axis 1 were found to be influenced by $\mathrm{pH}$. Keratella valaa located near the center of the ordination diagram, it was found to have a wide range of tolerance to changes in environmental variables.

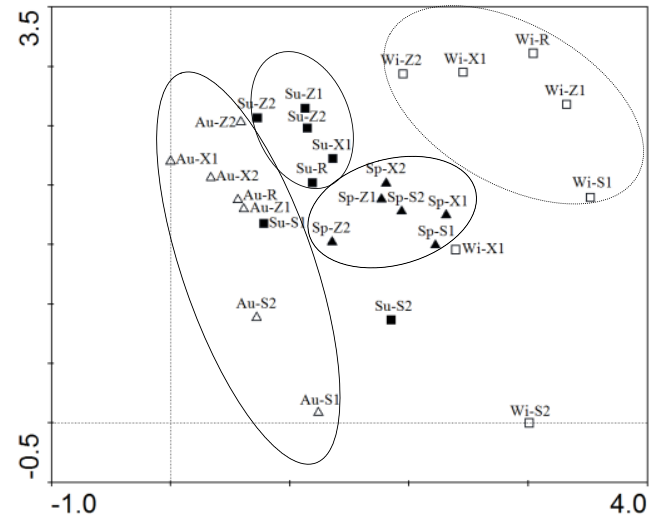

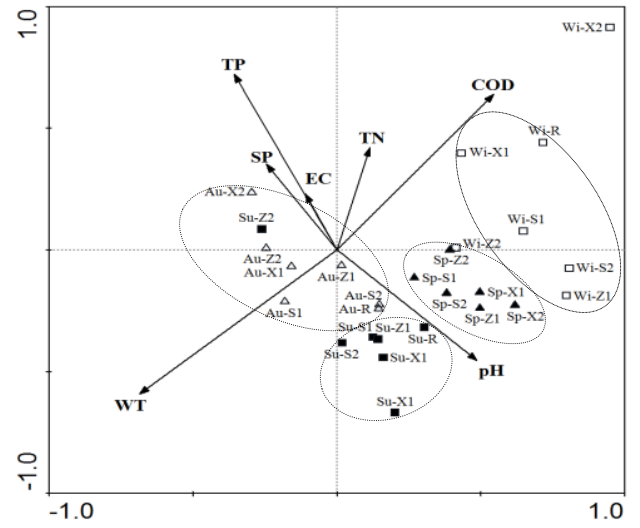

Figure 5. DCA ordination of the species abundance (a) and canonical correspondence analysis $(C C A)$ of the species-environment relationships (b). Samples collected in spring $(\mathbf{\Delta})$, summer $(\mathbf{\square})$, autumn ( $\Delta)$, and winter (). 


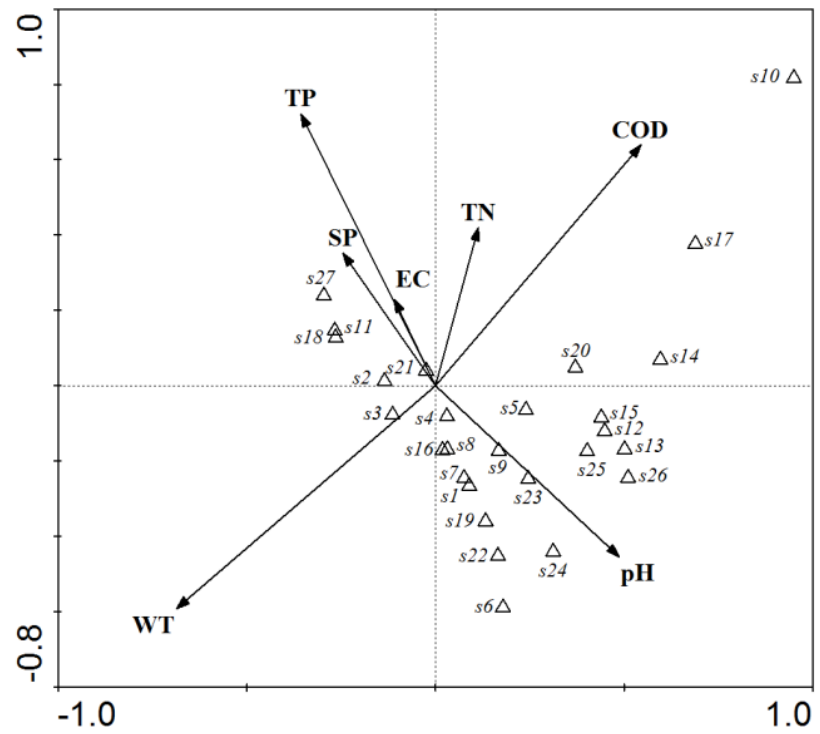

Figure 6. Ordination biplots of the main zooplankton species and environmental variables in Nanfei River (variables are represented by arrows. Species are depicted by triangles). Abbreviations: s1: Ceratium cornutum; s2: Euglena acus; s3: Euglena ehrenbergil; s4: Euglena gasterosteus; s5: Euglena geniculata; s6: Euglena oxyuris; s7: Euglena proxima; s8: Phacus triqueter; s9: Difflugia glans; s10: Askenasia volvox; s11: Epistylis sp.; s12: Paramecium caudatum; s13: Tintinnopsis wangi; s14: Vorticella campanula; s15: Vorticella sp.; s16: Brachionus angularis; s17: Brachionus calyciflorus; s18: Brachionus urceus; s19: Filinia longiseta; s20: Keratella cochlearis; s21: Keratella valaa; s22: Hexarthra mira; s23: Polyarthra trigla; s24: Rotaria neptunia; s25: Synchaeta pectindta; s26: Daphnia magna; s27: Moina affinis

Table 3. Summary results of the canonical correspondence analysis $(C C A)$

\begin{tabular}{lccc}
\hline & Axis 1 & Axis 2 & Axis 3 \\
\hline $\mathrm{WT}\left({ }^{\circ} \mathrm{C}\right)$ & -0.69 & -0.59 & -0.29 \\
$\mathrm{TP}(\mathrm{mg} / \mathrm{L})$ & -0.36 & 0.72 & 0.28 \\
$\mathrm{TN}(\mathrm{mg} / \mathrm{L})$ & 0.11 & 0.42 & 0.07 \\
$\mathrm{pH}$ & 0.49 & -0.45 & -0.55 \\
$\mathrm{COD}(\mathrm{mg} / \mathrm{L})$ & 0.55 & 0.64 & -0.39 \\
$\mathrm{SP}(\mathrm{mg} / \mathrm{L})$ & -0.25 & 0.35 & 0.67 \\
$\mathrm{EC}(\mathrm{us} / \mathrm{cm})$ & -0.11 & 0.23 & 0.55 \\
Eigenvalues & 0.43 & 0.25 & 0.21 \\
Species-environment correlations & 0.95 & 0.87 & 0.75 \\
Cumulative percentage variance & & & \\
of species data & 14.1 & 22.2 & 29.2 \\
of species-environment relation & 29.6 & 46.7 & 61.4 \\
\hline
\end{tabular}




\section{Discussion}

\section{Zooplankton community structure}

The Nanfei River flowing cross the Hefei City, is called as the mother river of Hefei City, and it is also a typical tributary of Chaohu Lake. Recently years, aquatic ecosystems of Nanfei River degenerate seriously. Pollution control and water quality improvement is imperative. Studies on zooplankton community and its relations to environmental factors in Nanfei River are relatively few. In this study, zooplankton community of Nanfei River was chracterized by presence of freshwater zooplankton, and most of the taxa are cosmopolitan. Some species belonging to the genera Askenasia, Epistylis, Euglena, Paramecium, Vorticella, Keratella, Brachionus and Polyarthra are typical in eutrophic water (Apaydın Yağcı and Ustaoğlu, 2012; Sláděcek, 1983). Microzooplankton (protozoa and rotifer) comprised a high proportion of species number and abundance. Eutrophication affects zooplankton composition and replaces the dominance from larger species to smaller species (Marneffe et al., 1996). Rotifer and protozoa have sufficient advantages (small individuals, fast growth, and short life cycle) and are more sensitive to the changes of aquatic environment factors than cladocera and copepoda. The Nanfei River was rich in planktivorous fish, such as Zacco platypus, Hemiculter leucisculus (Qian et al., 2016). Planktivorous fish typically prefer larger zooplankton, and they would reduce densities of cladocerans and copepods to a greater extent rather than the rotifers and protozoa (Havel et al., 2009). It is generally assumed that small rivers with relatively high current velocity is not suitable for reproduction of zooplankton, and high flow generally reduces the zooplankton density (Czerniawski and Domagała, 2010; Wu et al., 2008). Species number and abundance of zooplankton in the Nanfei River presented high value. Reasons are as follows: (1) Dongpu Reservoir in the upper reaches and some dams in the middle and lower reaches caused low water circulation of the Nanfei River, which was beneficial for zooplankton, especially for growth and reproduction of protozoa and rotifer; (2) the Nanfei River had a plenty of phytoplankton, including cyanobacteria, green algae, and diatoms, which provided plenty of food for zooplankton (Li et al., 2014b; Liu et al., 2015).

\section{Spatial and temporal variability of zooplankton community structure}

Zooplankton communities in rivers show marked spatial and temporal variation (Bonecker et al., 2005). The upper reaches, middle reaches, lower reaches, and the entrance of the Nanfei River represent extensive water trophic type, providing an ideal mode of studying on spatiotemporal heterogeneity of zooplankton community structure and its relationship with environmental factors. In this study, according to the UPGMA clustering of the physicochemical factors, samples within a season were generally clustered into the same group, stations of the upper reaches were dissimilar to stations of the middle and lower reaches, and the entrance (Fig. $2 a, b$ ), which showed higher spatial-temporal heterogeneity of habitat in Nanfei River. According to Fig. 3a, different stations had different species number and abundance of zooplankton, showing that zooplankton community structure of the Nanfei River had obvious spatial heterogeneity. DCA analysis results showed that the sampling stations were divided into four groups, indicating that zooplankton community structure of the Nanfei River had obvious temporal heterogeneity. 
It is widely accepted that species diversity and richness decrease in an aquatic community under stress conditions, such as heavy metals, extreme organic pollution, or a sharp change in any environmental factors, but some tolerant species broke out (Xu et al., 2005). The responses of zooplankton community along a spatial gradient of trophic level can be used for environmental monitoring (Gökçe and Özhan Turhan, 2014; Schindler, 1987). In this study, the differences of zooplankton community structure directly reflected the water quality of each sampling station. Species number in stations S1, S2, Z1, and Z2 were higher than stations $\mathrm{X} 1, \mathrm{X} 2$, and $\mathrm{R}$; stations Z2, X1 and X2 had the higher abundance, followed by station Z1, stations S1, S2, R had the lowest abundance (Fig. 3a); Shannon-Wiener index and Pielou evenness index of zooplankton in the upper reaches was higher than the middle and lower reaches, and the entrance (Fig. 4a). Based on species number, abundance, Shannon-Wiener index $\left(H^{\prime}\right)$ and Pielou evenness index $(J)$, it was found that water quality of upper reaches was better than the middle and lower reaches, and the entrance. As for each season, winter presented lowest species number, and higher nutrient concentrations than other seasons. River flow and water self-purification function decreased significantly and pollutant concentrations increased in dry winter. Therefore, water quality of winter was worse than other seasons.

\section{Zooplankton-environment relationship}

Because the presence or absence of zooplankton can be a relatively accurate predictor of water quality, they are often referred to as "indicator species" (Yu et al., 2016). In this study, the CCA analysis revealed that the crucial factors (water temperature, TP, TN, pH, COD, SP, and EC) influencing zooplankton composition and distribution are seasonally variable. Total nitrogen (TN) and total phosphorus (TP) are important environmental factors that influenced zooplankton community structure in freshwater ecosystem. Especially in highly eutrophic water, zooplankton community has an obvious response to the change of TN and TP (Jeppesen et al., 2000; Smith et al., 1999). Conductivity values were affected by human-induced pollution. The conductivity variation could be an important regulator of the structure of zooplankton assemblages, especially species diversity and species number (Williams, 1998). In this study, five species including Euglena acus, Euglena ehrenbergil, Epistylis sp., Brachionus urceus, and Moina affinis presented high abundance in summer and autumn, and were closer to each other on the CCA ordination axis indicating their similar ecological adaptations, and positive correlationship with TP, SP, EC, and TN, the increasing abundance of these five species acted as a good indicator of increasing levels of TP, SP, EC, and TN.

Water temperature is a major environmental factor influencing the growth and reproduction of zooplankton, and temperature has been reported as a positive correlate of zooplankton density (Czerniawski and Domagała, 2010; Yang et al., 2014). In the present study, the lowest zooplankton abundance was determined in winter at the lowest water temperature. The zooplankton abundance was increased with the increase of temperature in spring and summer. However, highest abundance was recorded in autumn. The zooplankton abundance in autumn was much higher than that in the other seasons. It was possible a result of water residence time increases in the dry season (autumn), phytoplankton biomass and abundance accumulated in the slow flowing waters. Therefore, zooplankton abundance increased when grazing conditions improve. Chemical oxygen demand (COD) is a comprehensive index of evaluating the degree of water pollution, higher COD is generally related to lower water quality, often due to organic and/or chemical pollution. In the present study, COD was highest in winter, and positively 
related to the structure of zooplankton community in winter. Sampling stations in winter were concentrated in the first and fourth quadrant, and COD affected zooplankton community structure more than any other environmental variables. Askenasia volvox and Brachionus calyciflorus appeared mainly in winter, and were positively correlated with COD and negatively with temperature, the occurrence of these two species indicated high-COD and low-temperature conditions. In this study, the distribution of 19 species of zooplankton was positively correlated with the $\mathrm{pH}$ (Fig. 6). Most of the biological processes and biochemical reactions depend on $\mathrm{pH}$; therefore it affects distribution of zooplankton (Berzins and Pejler, 1987; Ivanova and Kazantseva, 2006).

Wang (1985) used PFU method to monitor and evaluate the water quality of the Nanfei River, 152 species of protozoa were observed, and the dominant species was not obvious, species of pollution resistance were rare. In present study, 116 species of protozoa were found, and the number of pollution resistant species was increased. Compared to Wang (1985), water quality of the Nanfei River showed a further deterioration of the trend.

\section{Conclusions}

Based on zooplankton community structure, Shannon-Wiener index $(H)$, and Pielou evenness index $(J)$, water quality of Nanfei River was moderate pollution. Water temperature, total phosphorus, total nitrogen, $\mathrm{pH}$, chemical oxygen demanded, soluble phosphate, and conductance rate, were vital factors affecting the zooplankton community, and present study confirmed that zooplankton communities significantly respond to changes in the water quality of river. It should be noted that many factors, such as water quality, predation, and other environmental elements, may influence zooplankton community in aquatic ecosystems. It is premature to attempt an explanation for research on the zooplankton community in the Nanfei River.

Acknowledgements. This study was supported by the Visiting Research Foundation at Home and Abroad for the Outstanding Young Backbone Talents of Colleges and Universities of Anhui Province (No. gxfx2017082) and the 136 Talents Project of Hefei Normal University (No. 2014136KJC01). The authors are grateful to SUN Qingye and LI Yang from School of Resources and Environment Engineering, Anhui University for kindly providing physicochemical data of the Nanfei River.

\section{REFERENCES}

[1] Apaydın Yağc1, M., Ustaoğlu, M. R. (2012): Zooplankton fauna of Lake İznik (Bursa, Turkey). - Turkish Journal of Zoology 36: 341-350.

[2] Berzins, B., Pejler, B. (1987): Rotifer occurrence in relation to pH. - Hydrobiology 147: 107-116.

[3] Bonecker, C. C., Da Costa, C. L., Velho, L. F. M., Lansac-Tôha, F. A. (2005): Diversity and abundance of the planktonic rotifers in different environments of the upper Paraná river floodplain (Paraná State - Mato Grosso do Sul State, Brazil). - Hydrobiologia 546: 405-414.

[4] Czerniawski, R., Domagała, J. (2010): Similarities in zooplankton community between River Drawa and its two tributaries (Polish part of River Odra). - Hydrobiologia 638: 137-149. 
[5] Deng, X. J., Xu, Y. P., Zhai, L. X., Liu, Y., Li, Y. (2014): Establishment and application of the index system for for urban river health assessment. - Acta Ecologica Sinica 34: 993-1001.

[6] Dorak, Z. (2013): Zooplankton abundance in the lower Sakarya River Basin (Turkey): Impact of environmental variables. - Journal of the Black Sea / Mediterranean Environment 19: 1-22.

[7] Ergönül, M. B., Erdoğan, S., Altindağ, A., Atasağun, S. (2016): Rotifera and Cladocera fauna of several lakes from the Central Anatolia, Marmara, and Western Black Sea regions of Turkey. - Turkish Journal of Zoology 40: 141-146.

[8] Gaygusuz, Ö., Dorak, Z. (2013): Species composition and diversity of the zooplankton fauna of Darlik stream (İstanbul-Turkey) and its tributaries. - Journal of Fisheries Sciences.com 7(4): 329-343.

[9] Gökçe, D., Özhan Turhan, D. (2014): Evaluation of vertical and horizontal changes in community structure of zooplankton in a deep dam lake. - Turkish Journal of Zoology 38: 11-22.

[10] Havel, J. E., Medley, K. A., Dickerson, K. D., Angradi, T. R., Bolgrien, D. W., Bukaveckas, P. A., Jiche, T. M. (2009): Effect of main-stem dams on zooplankton communities of the Missouri River (USA). - Hydrobiologia 628: 121-135.

[11] Huang, X. F. (2000): Survey, Observation and Analysis of Lake Ecology. - Standard Press of China, Beijing.

[12] Ivanova, M. B., Kazantseva, T. I. (2006): Effect of water $\mathrm{pH}$ and total dissolved solids on the species diversity of pelagic zooplankton in lakes: A statistical analysis. - Russian Journal of Ecology 37: 264-270.

[13] Jeppesen, E., Jensen, J. P., Søndergaard, M., Lauridsen, T., Landkildehus, F. (2000): Trophic structure, species richness and biodiversity in Danish lakes: changes along a phosphorus gradient. - Freshwater Biology 45: 201-218.

[14] Li, X. Y., Yu, H. X., Ma, C. X. (2014a): Zooplankton community structure in relation to environmental factors and ecological assessment of water quality in the Harbin section of the Songhua River. - Chinese Journal of Oceanology and Limnology 32: 1344 -1351.

[15] Li, Z., Guo, W. J., Cheng, S. P., Chai, P. H., Liang, W., Wu, Z. B. (2014b): The spatial and temporal distribution of chlorophyll-a and its correlation with environmental factor in the Nanfeihe River. - Acta Ecologica Sinica 38: 342-350.

[16] Lin, Q., You, W. H., Xu, F. J., Yu, Q. J., Yu, H. G. (2014): Zooplankton community structure and its relationship with environmental factors in Dishui Lake. - Acta Ecologica Sinica 34: 6918-6929.

[17] Liu, E. S., Wang, H., Ou, J. H., Tang, K. C., Yang, S. (2015): Changes of phytoplankton in a multi-stage bypass constructed wetland on Nanfei River: a water purification demonstration project. - Journal of Hydroecology 36: 19-24.

[18] Marneffe, Y., Descy, J. P., Thomé, J. P. (1996): The zooplankton of the lower river Meuse, Belgium: seasonal changes and impact of industrial and municipal discharges. Hydrobiologia 319: 1-13.

[19] Ning, N. S. P., Gawne, B., Cook, R. A., Nielsen, D. L. (2013): Zooplankton dynamics in response to the transition from drought to flooding in four Murray-Darling Basin rivers affected by differing levels of flow regulation. - Hydrobiologia 702: 45-62.

[20] de Paggi, S. B. J., Devercelli, M. (2011): Land use and basin characteristics determine the composition and abundance of the microzooplankton. - Water Air \& Soil Pollution 218: 93-108.

[21] Pielou, E. C. (1966): Species-diversity and pattern-diversity in the study of ecological succession. - Journal of Theoretical Biology 10: 370-383. 
[22] Qian, H., Yan, Y. Z., Chu, L., Zhu, R., Gao, J. F., Cai, Y. J. (2016): Spatial and temporal patterns of fish assemblages in the rivers of Chaohu Basin. - Resources and Environment in the Yangtze Basin 25: 257-264.

[23] Reckendorfer, W., Keckeis, H., Winkler, G., Schiemer, F. (1999): Zooplankton abundance in the River Danube, Austria: the significance of inshore retention. - Freshwater Biology 41: 583-591.

[24] Roman, M. R., Pierson, J. J., Kimmel, D. G., Boicourt, W. C., Zhang, X. (2012): Impacts of hypoxia on zooplankton spatial distributions in the Northern Gulf of Mexico. - Estuaries and Coasts 35: 1261-1269.

[25] Schindler, D. W. (1987): Detecting ecosystem responses to anthropogenic stress. Canadian Journal of Fisheries and Aquatic Sciences 44: 6-25.

[26] Sellami, I., Guermazi, W., Hamza, A., Aleya, L., Ayadi, H. (2010): Seasonal dynamics of zooplankton community in four Mediterranean reservoirs in humid area (Beni Mtir: north of Tunisia) and semiarid area (Lakhmes, Nabhana and Sidi Saâd: center of Tunisia). Journal of Thermal Biology 35: 392-400.

[27] Shah, D. N., Tachamo, R. D. (2009): The cause and implication of urban river pollution: Mitigative measures and benthic macroinvertebrates as river monitoring tool (p. 419-424). - In: Feyen, J., Shannon, K., Neville, M. (eds.) Water and Urban Development Paradigms: Towards and Integration of Engineering, Design and Management Approaches. Taylor \& Francis Group, London.

[28] Shannon, C. E., Weaver, W. (1949): The Mathematical Theory of Communication. University of Illinois Press, Urbana.

[29] Sharma, S., Siddique, A., Singh, K., Chouhan, M., Vyas, A., Solnki, C. M., Sharma, D., Nair, S., Sengupta, T. (2010): Population dynamics and seasonal abundance of zooplankton community in Narmada River (India). - Researcher 2: 1-9.

[30] Shen, Y. F., Zhang, Z. S., Gong, X. J., Gu, M. R., Shi, Z. X., Wei, Y. X. (1990): Modern Biomonitoring Techniques Using Freshwater Microbiota. - China Architecture and Building Press, Beijing.

[31] Sláděcek, V. (1983): Rotifers as indicators of water quality. - Hydrobiologia 100: 169-201.

[32] Smith, V. H., Tilman, G. D., Nekola, J. C. (1999): Eutrophication: impacts of excess nutrient inputs on freshwater, marine, and terrestrial ecosystems. - Environmental Pollution 100: 179-196.

[33] Song, Q. H., Yang, Z. F. (2002): Thinking of integrated management of urban rivers in China. - Advances in Water Resources 13: 377-382.

[34] Sousa, W., Attayde, J. L., da Silva Rocha, E., Eskinazi-Sant'Anna, E. M. (2008): The response of zooplankton assemblages to variations in the water quality of four man-made lakes in semi-arid northeastern Brazil. - Journal of Plankton Research 30: 699-708.

[35] Swaney, D. P., Hong, B. T. C., Howarth, R. W., Humborg, C. (2012): Net anthropogenic nitrogen inputs to watersheds and riverine $\mathrm{N}$ export to coastal waters: a brief overview. Current Opinion in Environmental Sustainability 4: 203-211.

[36] Vincent, K., Mwebaza-Ndawula, L., Makanga, B., Nachuha, S. (2012): Variations in zooplankton community structure and water quality conditions in three habitat types in northern Lake Victoria. - Lakes \& Reservoirs: Research and Managment 17: 83-95.

[37] Wang, J. L. (1985): Water quality in Nanfei River, Using PFU protozoan communities as indicators. - Environmental Science 8: 70-73.

[38] Wang, J. Y. (1961): Freshwater Rotifers Record of China. - Science Press, Beijing.

[39] Williams, W. D. (1998): Salinity as a determinant of the structure of biological communities in salt lakes. - Hydrobiologia 381: 191-201.

[40] Wu, L., Feng, W. S., Chen, X. J., Shu, F. Y., Liang, X. M. (2008): Characterstics of zooplankton community structure during the summer in Yili region, Xinjiang. - Chinese Journal of Applied Ecology 19: 163-172. 
[41] Xu, M. Q., Cao, H., Xie, P., Deng, D. G., Feng, W. S., Xu, J. (2005): The temporal and spatial distribution, composition and abundance of planktonic protozoa, with special relation to eutrophication in the Chaohu Lake, China. - European Journal of Protistology 41: 183-192.

[42] Yang, W., Deng, D. G., Zhang, S., Hu, C. L. (2014): Seasonal dynamics of crustacean zooplankton community structure in Erhai Lake, a plateau lake, with reference to phytoplankton and environmental factors. - Chinese Journal of Oceanology and Limnology 32: 1074-1082.

[43] Yu, N., Li, E. C, Feng, D. X., Xiao, B. C., Wei, C. Q., Zhang, M. L., Chen, L. Q. (2014): Correlations between zooplankton assemblages and environmental factors in the downtown rivers of Shanghai, China.- Chinese Journal of Oceanology and Limnology 32: 1352-1363.

[44] Zhang, Z. S., Huang, X. F. (1991): Research Methods of Freshwater Plankton. - Science Press, Beijing.

[45] Zhang, R., Zeng, F. X., Liu, W. J., Zeng, R. J., Jiang, H. (2014): Precise and economical dredging model of sediments and its field application: case study of a river heavily polluted by organic matter, nitrogen, and phosphorus. - Journal of Environmental Management 53: 1119-1131. 


\section{APPENDIX}

Appendix 1. Distribution of zooplankton species at sampling stations in Nanfei River

\begin{tabular}{|c|c|c|c|c|c|c|c|c|c|c|c|c|c|c|c|c|c|c|c|c|c|c|c|c|c|c|c|c|}
\hline & \multicolumn{7}{|c|}{ Spring } & \multicolumn{7}{|c|}{ Summer } & \multicolumn{7}{|c|}{ Autumn } & \multicolumn{7}{|c|}{ Winter } \\
\hline & S1 & S2 & $\mathbf{Z 1}$ & $\mathbf{Z 2}$ & X1 & $\mathbf{X} 2$ & $\mathbf{R}$ & S1 & $\mathbf{S 2}$ & $\mathbf{Z 1}$ & $\mathbf{Z 2}$ & $\mathrm{X} 1$ & $\mathbf{X} 2$ & $\mathbf{R}$ & S1 & $\mathbf{S 2}$ & $\mathbf{Z 1}$ & $\mathbf{Z 2}$ & $\mathbf{X 1}$ & $\mathbf{X} 2$ & $\mathbf{R}$ & S1 & $\mathbf{S 2}$ & $\mathbf{Z 1}$ & $\mathbf{Z 2}$ & X1 & $\mathbf{X} 2$ & $\mathbf{R}$ \\
\hline \multicolumn{29}{|l|}{ Protozoa } \\
\hline Astasia sp. & & & & & & & & & & & & & & & & + & + & & & & & & & & & & & \\
\hline Ceratium cornutum & & + & + & & & & & & + & & & & & + & + & + & & + & & + & + & & + & & & & & \\
\hline Cryptomonas sp. & & + & & & & & & & & & & & & & & & & & & & & & & & & & & \\
\hline Dinobryon sociale & + & + & & & & & & & & & & & & & & & & & & & & & & & & & & \\
\hline Eudorina elegans & + & + & & & & & & & & & & & + & & & & & & & & & & & & & & & \\
\hline Euglena acus & & & & & & & & & & & & & & & & + & + & + & + & + & + & & & & & & & \\
\hline Euglena clavata & & & & & & & & & & & & & & & & + & + & + & + & + & & & & & & & & \\
\hline Euglena communis & & & & & & & & & & & & + & & & & & & & & & & & & & & & & \\
\hline Euglena cuneata & & & & & & & & & & & + & + & & & & & & & & & & & & & & & & \\
\hline Euglena deses & & & & & & & & & & & & & & & & & & & & + & & & & & & & & \\
\hline Euglena pisciformis & & & + & & & & & & & & & & & & & & & & & & & & & & & & & \\
\hline Euglena ehrenbergil & & & & & & & & + & & & + & + & + & & & & & & + & + & + & & & & & + & & \\
\hline Euglena gasterosteus & & & + & + & & & & & & + & + & + & + & & & + & + & + & + & + & + & & & & & & & \\
\hline Euglena geniculata & & & + & + & & & & & & & + & & & & + & + & + & & & & & & & & & & & \\
\hline Euglena multiformis & & & & & & & & & & & & + & & & & & & & & + & & & & & & & & \\
\hline Euglena mutabilis & & & & & & & & & & & & & & & & + & + & & + & + & & & & & & & & \\
\hline Euglena oxyuris & & & + & & & + & & + & & + & + & + & + & + & & + & + & + & + & + & + & & & & + & + & & \\
\hline Euglena proxima & & & + & & & & & + & & & + & + & & & & + & + & & & & & & & & & & & \\
\hline Euglena pisciformis & & & & & & & & & + & & & & & & & & & & & & & & & & & & & \\
\hline Euglena spirogyra & & & & & & & & + & & & & + & & & & & & & & & & & & & & & & \\
\hline Euglena interrupta & & & & & & & & + & & & & & & & & & & & & & & & & & & & & \\
\hline Euglena sp.1 & & & & & & & & & & & & & & & & + & + & + & + & + & & & & & & & & \\
\hline Euglena sp.2 & & & & & & & & & & & & & & & & & + & & & & & & & & & & & \\
\hline Euglena sp. 3 & & & & & & & & & & & & & & & & & & & + & & & & & & & & & \\
\hline Euglena sp.4 & & & + & & & & & & & & & & & & & & & & & & & & & & & & & \\
\hline Euglena sp.5 & & & & & + & & & & & & & & & & & & & & & & & & & & & & & \\
\hline
\end{tabular}

APPLIED ECOLOGY AND ENVIRONMENTAL RESEARCH 15(3): 1417-1442.

http://www.aloki.hu • ISSN 15891623 (Print) • ISSN 17850037 (Online)

DOI: http://dx.doi.org/10.15666/aeer/1503_14171442

(c) 2017, ALÖKI Kft., Budapest, Hungary 


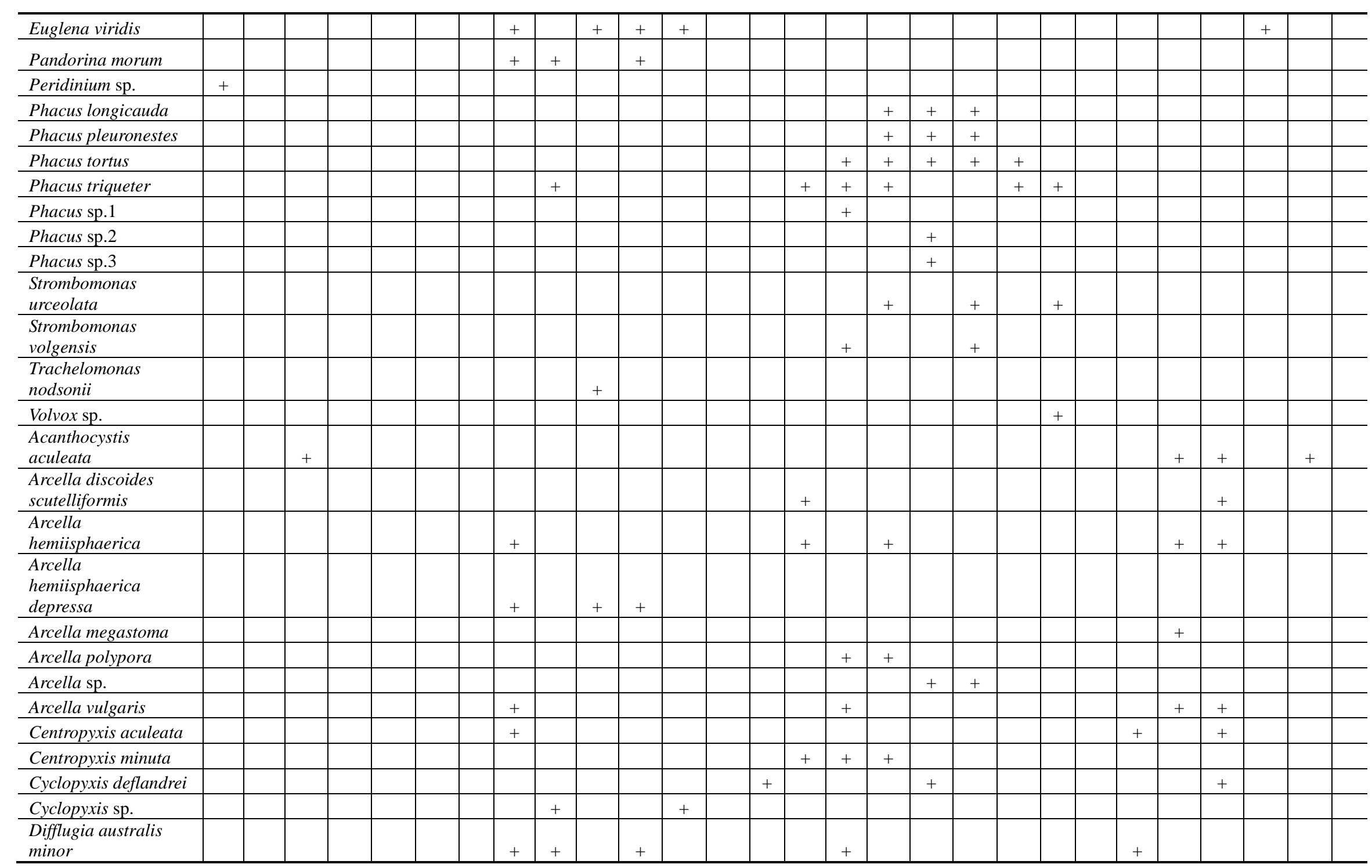

APPLIED ECOLOGY AND ENVIRONMENTAL RESEARCH 15(3): 1417-1442.

http://www.aloki.hu • ISSN 15891623 (Print) • ISSN 17850037 (Online)

DOI: http://dx.doi.org/10.15666/aeer/1503_14171442

(c) 2017, ALÖKI Kft., Budapest, Hungary 


\begin{tabular}{|c|c|c|c|c|c|c|c|c|c|c|c|c|c|c|c|c|c|c|c|c|c|c|c|c|c|c|c|c|}
\hline Difflugia avellana & & & & & & & & & & + & & & & & & & + & & & & & & & & & & & \\
\hline Difflugia biwae & & & & & & & & & & & & & & & & + & & & & & & & & & & & & \\
\hline Difflugia difficilis & + & & & & & & & + & + & & & & & & + & + & + & & & & & & & & & + & & \\
\hline Difflugia fallax & & & & & & & & & & & & & & & & & + & & & & & & + & & & & & \\
\hline Difflugia glans & & & & & & & & + & + & & & & & & + & + & + & & & & + & & + & & & + & & \\
\hline Difflugia globulosa & & & & & & & & + & + & & & & & & + & + & & & & & + & & + & & & & & \\
\hline $\begin{array}{l}\text { Difflugia globulosa } \\
\text { gramen }\end{array}$ & & & & & & & & + & & & & & & & & & & & & & & & & & & & & \\
\hline Difflugia gramen & & & & & & & & + & & & & & & & & + & & & & & & & & & & & & \\
\hline $\begin{array}{l}\text { Difflugia lismorensis } \\
\text { elongata }\end{array}$ & & & & & & & & + & & & & & & & & & & & & & & & & & & & & \\
\hline Difflugia lobostoma & & & & & & & & & & & & & & & & & & & & + & & & & & & & & \\
\hline Difflugia lucida & & & & & & & & + & & & & & & & & & & & & & & & & & & & & \\
\hline Difflugia mulanensis & & & & & & & & & & & & & & & & + & & & & & & & & & & & & \\
\hline $\begin{array}{l}\text { Difflugia oblonga } \\
\text { cylindrus }\end{array}$ & & & & & & & & + & + & & & & & & & & & & & & & & & & & & & \\
\hline Difflugia pyriformst & & & & & & & & & & & + & & & & & & & & & & & & & & & & & \\
\hline Difflugia sp.1 & & & & & & & & & & & & & & & & + & & & & & & & & & & & & \\
\hline Difflugia sp.2 & & & & & & & & & & & & & & & & + & & & & & & & & & & & & \\
\hline $\begin{array}{l}\text { Difflugia } \\
\text { tuberspinifera }\end{array}$ & & & & & & & & & & & & & & & & + & + & & & & & & & & & & & \\
\hline Difflugia urceolata & & & & & & & & + & & & & & & & & + & & & & & & & & & & & & \\
\hline Hartmanella sp. & & & & & & & & & & & & & & & & & & & & & & & & + & & & & \\
\hline Acineta foetida & & & & & & & & & & & & & & & & & & & & & & & & & + & & & \\
\hline Askenasia volvox & & + & & & & & & & & & & & & & & & & & & & & & & + & + & + & + & + \\
\hline Litonotus obtusus & & & & & & & & & & + & & & & & & & & & & & & & & & & & & \\
\hline Frontonia acuminata & & & & & & & & & & + & & & & & & & & & & & & & & & & & & \\
\hline Ciliate 1 & & & & & & & & & & & & & & & & + & & & & & & & & & & & & \\
\hline Ciliate 2 & + & & & & & & & & & & & & & & & & & & & & & & & & & & & \\
\hline Ciliate 3 & & + & & & & & & & & & & & & & & & & & & & & & & & & & & \\
\hline Ciliate 4 & & + & & & & & & & & & & & & & & & & & & & & & & & & & & \\
\hline Ciliate 5 & & & + & & & & & & & & & & & & & & & & & & & & & & & & & \\
\hline Colpoda sp. & & & & & & & & & & & & & & & & + & + & & + & & & & & & & & & \\
\hline Didinium balbianii & & & + & & & & & & & & & & & & & & & & & & + & & + & & & & & \\
\hline Didinium nasutum & & & & + & & & & & & & & & & & & & & & & & & & & & & & & \\
\hline
\end{tabular}

APPLIED ECOLOGY AND ENVIRONMENTAL RESEARCH 15(3): 1417-1442.

http://www.aloki.hu • ISSN 15891623 (Print) • ISSN 17850037 (Online)

DOI: http://dx.doi.org/10.15666/aeer/1503_14171442

(c) 2017, ALÖKI Kft., Budapest, Hungary 


\begin{tabular}{|c|c|c|c|c|c|c|c|c|c|c|c|c|c|c|c|c|c|c|c|c|c|c|c|c|c|c|}
\hline Dileptus anser & & + & & & & & & & & & & & + & & + & & & & & & & & & & & \\
\hline Epistylis sp. & & & + & + & & & & & & & & & & + & & + & + & + & & & & & + & & + & \\
\hline Epistylis plicatilis & & & & & & & & & + & & & & & & & & & & & & & & & & & \\
\hline Glaucoma sp. & & & & & & & & & & & & & + & + & & & & & + & & & & & & & \\
\hline Halterria gradinella & & & & & & & & & & & & & & & & & & & & & + & & & & & \\
\hline $\begin{array}{l}\text { Hemiophrys } \\
\text { meleagris }\end{array}$ & & & + & + & & & & & & & & & & & & & & & & & & & & & & \\
\hline Hemiophrys punctata & & & & & & & & & + & & & & & & & & & & & & & & & & & \\
\hline $\begin{array}{l}\text { Lagynophrya } \\
\text { mucicola }\end{array}$ & & & + & + & & & & & + & & & & & & & & & & & & & & & & & \\
\hline Leprotintinnus sp. & & & & & & & & & & & & & & & & & & & & & + & & & & & \\
\hline Lionotus sp. & & & & & + & & & & & & & & & & & & & & & & & + & + & + & & \\
\hline Opercularia sp. & & & + & + & & & & & & & & & & & & & & & & & & & + & & & \\
\hline Peritrichida & & & + & & & & & & & & & & & & & & & & & & & & & & & \\
\hline $\begin{array}{l}\text { Paramecium } \\
\text { caudatum }\end{array}$ & & + & + & + & + & & & & + & & + & + & & & + & & + & + & + & & & + & + & + & + & \\
\hline Paramecium sp. & & & & & & & & & & & & & & & + & & + & + & & & & & & & & \\
\hline Spathidium sp. & & & & & & & & & & & & & & & + & & & & & & & & & & & \\
\hline Tetrahymena sp. & & & & & & & & + & & & + & & + & + & & & & & & & & & & & & \\
\hline Tintinnidium fluviatile & & & & & & & & & & & & & & + & & & & & & & & & + & & & \\
\hline Tintinnopsis conus & & & & & & & & & & & & & & & & & & & & & + & & & & & \\
\hline Tintinnopsis longus & + & & & & & & & & & & & & & & & & & & & + & & & & & & \\
\hline Tintinnopsis sinensis & & & & & & + & & & & & & & & & & & & & & & & & & & & \\
\hline $\begin{array}{l}\text { Tintinnopsis } \\
\text { tutuformis }\end{array}$ & & & & & & + & & & & & & & & & & & & & & + & & & & & & \\
\hline Tintinnopsis wangi & & & + & & & + & + & & & & & & + & + & & & & & & & + & & & & & + \\
\hline Tokphrya infusiomum & & & & + & & & & & & & & & & & & & & & & & & & & & & \\
\hline Tokphrya quadipatita & & & & & + & & & & & & & & & & & & & & & & & & & & & \\
\hline Uroleptus sp. & & & & & & + & & & & & & & & & & & & & & & & & & & & \\
\hline Vorticella campanula & & + & & & & & & & & & & & & & & & + & & & + & & + & + & & + & + \\
\hline Vorticella sp.1 & & & & & & & & & & & & & & & + & & & & & & & & & & & \\
\hline Vorticella sp. 2 & & & & & & & & & & & & & & & & + & + & & & & & & & & & \\
\hline Vorticella sp.3 & + & + & + & + & + & + & & & & & & & & & & & & & & & & & & & & \\
\hline Vorticella sp.4 & & & & & & & & & & + & & & & & & & & & & & & & & & & \\
\hline Vorticella sp.5 & & & & & & & & & + & & & & & & & & & & & & & & & & & \\
\hline
\end{tabular}

APPLIED ECOLOGY AND ENVIRONMENTAL RESEARCH 15(3): 1417-1442.

http://www.aloki.hu • ISSN 15891623 (Print) • ISSN 17850037 (Online)

DOI: http://dx.doi.org/10.15666/aeer/1503_14171442

(c) 2017, ALÖKI Kft., Budapest, Hungary 


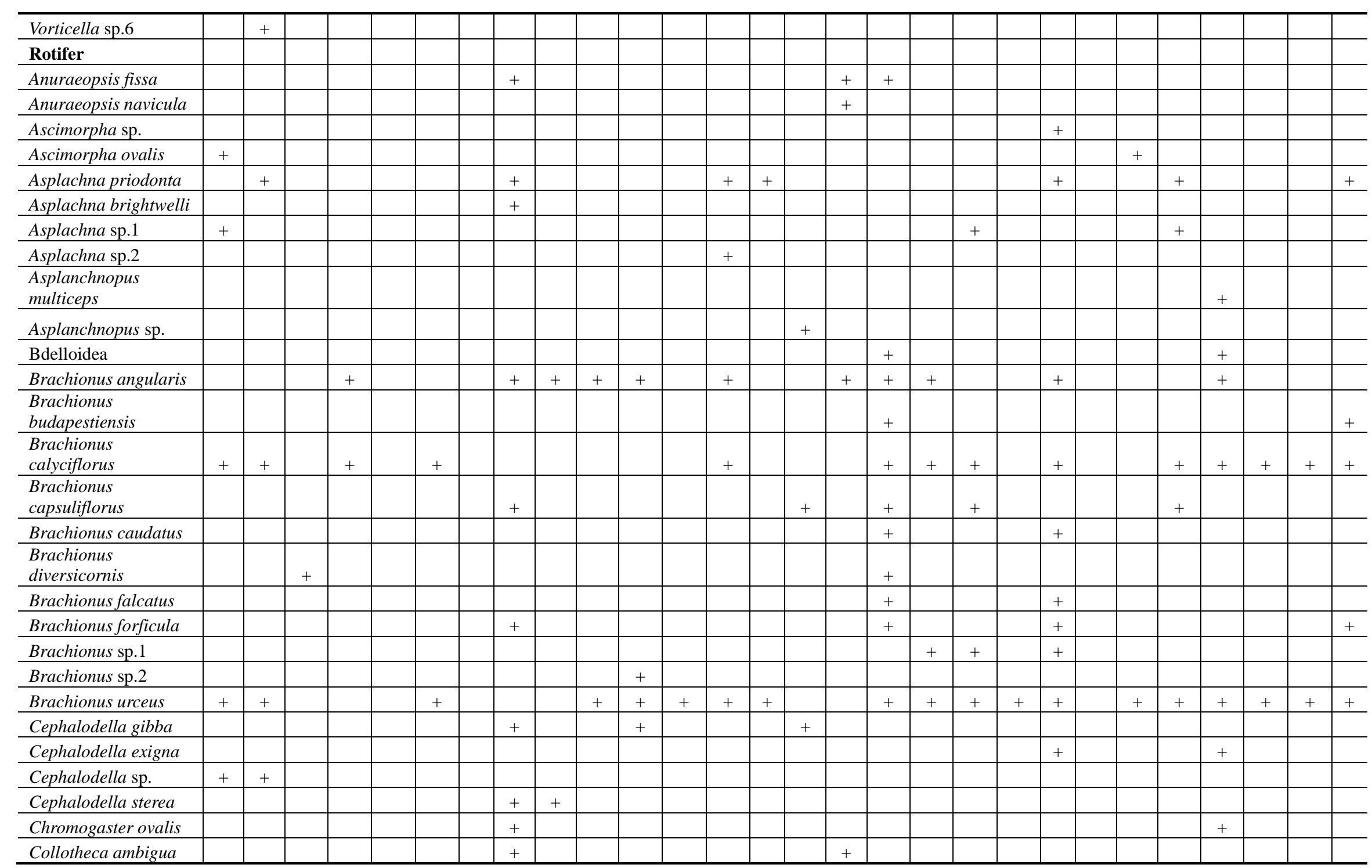

APPLIED ECOLOGY AND ENVIRONMENTAL RESEARCH 15(3): 1417-1442.

http://www.aloki.hu • ISSN 15891623 (Print) • ISSN 17850037 (Online)

DOI: http://dx.doi.org/10.15666/aeer/1503_14171442

(c) 2017, ALÖKI Kft., Budapest, Hungary 


\begin{tabular}{|c|c|c|c|c|c|c|c|c|c|c|c|c|c|c|c|c|c|c|c|c|c|c|c|c|c|c|}
\hline Colurella adriatica & + & + & & & & & + & + & & & & & & + & & + & & & & & & + & & & & \\
\hline Colurella sp. & & & & & & & & & & + & & & & & & & & & & & & & & & & \\
\hline $\begin{array}{l}\text { Conochilus } \\
\text { hippocrepis }\end{array}$ & & & & & & & + & & & & & & & & & & & & & & & & & & & \\
\hline Conochilus unicornis & & & + & + & & + & & & & & & & & + & & & & & & & & & & & & + \\
\hline $\begin{array}{l}\text { Dicranophorus } \\
\text { caudatus }\end{array}$ & & & & & & & & & & & & & & & & & & + & & & & & & & & \\
\hline $\begin{array}{l}\text { Dicranophorus } \\
\text { forcipatus }\end{array}$ & & & & & & & & & & & & & & & & & & & & & & + & + & & & \\
\hline Diurella bedens & & & & & & & & + & + & & & & & & & & & & & & & & & & & \\
\hline Diurella collaris & & & & & & & & + & & & & & & & & & & & & & & & & & & \\
\hline Diurella dixonnuttalli & & & & & & & & + & & & & & & & & & & & & & & & & & & \\
\hline Diurella rousseoeti & & & & & & & & & & & & & & & + & & & & & & & & & & & \\
\hline Diurella tenuior & & & & & & & + & & & & & & & + & & & & & & & & & & & & \\
\hline Epiphanes bravulatus & & & & & & & & & & & & & & & & & & & & & & + & & & & \\
\hline Epiphanes senla & & & & & & & & & & + & & & & & & & & & & & & & & & & \\
\hline Epiphanes sp. & & & & & & & & & & & & & & & & & & + & & & & & & & & \\
\hline Euchlanis dilatata & & + & & & & & & & & & & & & + & & & & & & & & & & & & \\
\hline Euchlanis pellucida & & & & & & & & + & & & & & + & & & & & & & & & + & & & & \\
\hline Euchlanis sp.1 & & & & & & & & & & & & & & + & + & + & & & & & & & & & & \\
\hline Euchlanis sp.2 & & & & & & & & & & & & & & & & & & + & & & & & & & & \\
\hline Euchlanis triquetra & & & & & & & & & & & & & & + & + & + & & & & & & & & & & \\
\hline $\begin{array}{l}\text { Eudactylota } \\
\text { eudactylota }\end{array}$ & & & & & & & + & & & & & & & & + & & & & & & & & & & & \\
\hline Filinia longiseta & + & & & + & + & & + & + & & + & + & + & & & & + & + & + & + & + & + & + & & & & \\
\hline Filinia opoliensis & & & & & & & & & & & & & & & & & & & & + & & + & & & & \\
\hline Hexarthra mira & & & + & & & & & & + & + & + & + & & & & & + & + & & + & & & & & & \\
\hline Keratella cochlearis & + & + & + & & & & + & + & + & + & & + & & & + & & & & & + & + & & & + & + & + \\
\hline KeratelIa valaa & & & + & & & & & & + & + & & + & & & & + & & & & + & & + & + & + & + & + \\
\hline Kerateua quadrata & + & + & & & + & & & & & & & & + & & & & & & & & & & & & & + \\
\hline $\begin{array}{l}\text { Lacinularia } \\
\text { flosculosa }\end{array}$ & & & & & & & & & & & & & & & & & & & & & & & + & & & \\
\hline Lecane luna & & & & & & & + & & + & & & & & & & & & & & & & & & & & \\
\hline Lecane nodosa & & & & & & & & & & & & & & + & + & + & + & & & + & & & & & & \\
\hline Lecane ploenensis & & & & & & & & & & + & & & & & & & & & & & & & & & & \\
\hline
\end{tabular}

APPLIED ECOLOGY AND ENVIRONMENTAL RESEARCH 15(3): 1417-1442.

http://www.aloki.hu • ISSN 15891623 (Print) • ISSN 17850037 (Online)

DOI: http://dx.doi.org/10.15666/aeer/1503_14171442

(c) 2017, ALÖKI Kft., Budapest, Hungary 


\begin{tabular}{|c|c|c|c|c|c|c|c|c|c|c|c|c|c|c|c|c|c|c|c|c|c|c|c|c|c|c|c|}
\hline Lecane sp. 1 & & & & & & & & & & & & & & & & & + & & & & & & & & & & \\
\hline Lecane sp. 2 & & & & & & & & & & & & & & & & & & & + & & & & & & & & \\
\hline Lecane sp. 3 & & & & & & & & + & & & & & & & & & & & & & & & & & & & \\
\hline Lecane tenuiseta & & & & & & & & + & & & & & & & & & & & & & & & & & & & \\
\hline Lecane ungulata & & & & & & & & + & & & & & & + & + & + & & & & & & & & & & & \\
\hline Lepadella patella & + & + & & & & & & & & & & & & + & + & & & & & & & & & & & & \\
\hline Lindia $\mathrm{sp}$. & & & & & & & & + & & & & & & & & & & & & & & & & & & & \\
\hline Lophocharis salpina & & & & & & & & & & & & & & + & & & & & & & & & & & & & \\
\hline Platyias quadricornis & & & & & & & & & & & & & & & & & & & & & & & + & & & & \\
\hline Polyarthra trigla & + & + & + & & & + & + & + & + & + & + & + & + & + & + & + & & & & + & + & + & + & + & + & + & + \\
\hline Pompholyx sulcata & + & & & & & & & & & & & & & & & + & & & & + & & & & & & & \\
\hline Monostyla bulla & & & & + & & & + & & + & & & & & & + & + & & & & + & & & + & + & & & \\
\hline Monostyla cornuta & & & & & & & + & & & & & & & & & & & & & + & & & + & + & & & \\
\hline Monostyla crenata & & & & & & & & & & & & & & & + & & & & & & & & & & & & \\
\hline Monostyla furcata & & & & & & & + & & & & & & & & & & & & & & & & & & & & \\
\hline Monostyla lunaris & & + & & & & & & + & & & & & & + & + & & & & & & & & & & & & \\
\hline Monostyla pyriformis & & & & & & & & & & & & & & + & & & & & & + & & & & + & & & \\
\hline Monostyla sp.1 & & & & & & & & & & & & & & & + & & & & & & & & & & & & \\
\hline Monostyla sp.2 & & & & & & & & & & & & & & & & + & & & & & & & & & & & \\
\hline Monostyla sp.3 & & & & & & & & & & & & & & & & & & & & & & + & & & & & \\
\hline Monostyla sp.4 & & & & & & & & & & & & & & & & & & & & & & & + & & & & \\
\hline Monostyla unguitata & & & & + & & & & & & & & & & & & & & & & & & & & + & & & + \\
\hline Mytilina ventralis & & + & & & & & & & & & & & & & & & & & & & & & & & & & \\
\hline Notholca labis & + & + & & & & & & & & & & & & & & & & & & & & & + & & & & \\
\hline Notholca sp. & & & & & & & & & & & & & & & & & & & & & & & & + & & & \\
\hline Notommata cyrtopus & & & & & & & & & & & & & + & & & & & & & & & & & & & & \\
\hline Rotaria neptunia & & & + & + & + & & & & & & + & + & & & & + & & + & & + & & & + & + & + & + & \\
\hline Rotaria rotatoria & & & & & & & & & & & & + & & & & & & + & + & & & & & + & & & \\
\hline Rotaria sp.1 & & & & & & & & + & & & & & & & & & & & & & & & & & & & \\
\hline Rotaria sp. 2 & & & & & & & & & & & + & & & & & & & & & & & & & & & & \\
\hline Rotaria sp. 3 & & & & & & & & & & & + & & & & & & & & & & & & & & & & \\
\hline Rotaria tardigrada & & & & & & & + & & & & & & & & & & & & + & & & & & + & & & \\
\hline Rotifera 1 & & & + & & & & & + & & + & & + & & & + & + & + & & & + & & & + & + & & & \\
\hline
\end{tabular}

APPLIED ECOLOGY AND ENVIRONMENTAL RESEARCH 15(3): 1417-1442.

http://www.aloki.hu • ISSN 15891623 (Print) $\bullet$ ISSN 17850037 (Online)

DOI: http://dx.doi.org/10.15666/aeer/1503_14171442

(c) 2017, ALÖKI Kft., Budapest, Hungary 


\begin{tabular}{|c|c|c|c|c|c|c|c|c|c|c|c|c|c|c|c|c|c|c|c|c|c|c|c|c|c|c|}
\hline Rotifera 2 & & & & & & & & & & & & & & & & + & & & & & & & & & & \\
\hline Rotifera 3 & & & & & & & & & & & & & & + & & & & & & & & & & & & \\
\hline Rotifera 4 & & & & & & & & & & & & & & & & & & & & & + & & & & & \\
\hline Rotifera 5 & & & & & & & & & & & & & & & & & & & & & & & & + & & \\
\hline Rotifera 6 & & + & & & & & & & & & & & & & & & & & & & & & & & & \\
\hline Rotifera 7 & & + & + & & & & & & & & & & & & & & & & & & & & & & & \\
\hline Rotifera 8 & & & + & + & & & & & & & & & & & & & & & & & & & & & & \\
\hline Rotifera 9 & & & & + & & & & & & & & & & & & & & & & & & & & & & \\
\hline Rotifera 10 & & & & & + & & & & & & & & & & & & & & & & & & & & & \\
\hline Rotifera 11 & & & & & & & + & & & & & & & & & & & & & & & & & & & \\
\hline Rotifera 12 & & & & & & & & & + & & & & & & & & & & & & & & & & & \\
\hline Rotifera 13 & & & & & & & & & & + & & & & & & & & & & & & & & & & \\
\hline Rotifera 14 & & & & & & & & & & & + & & & & & & & & & & & & & & & \\
\hline $\begin{array}{l}\text { Scaridum } \\
\text { longicaudum }\end{array}$ & & & & & & & & & & & & & & + & + & & & & & & & & & & & \\
\hline Synchaeta grandis & & & & & & & & + & & & & & & & & & & & & & & & & & & \\
\hline Synchaeta pectindta & + & + & & & & & + & + & & & & & & & & & & & & & + & + & + & & & + \\
\hline Synchaeta sp.1 & & & & & & & & & & & & & & & + & + & & & & & & & & & & \\
\hline Synchaeta sp.2 & & & & + & & & & & & & & & & & & & & & & & & & & & & \\
\hline Synchaeta sp.3 & & & & & & & + & & & & & & & & & & & & & & & & & & & \\
\hline Testudinella patina & & & & & & & + & & & & & & & & & + & & & & & & & + & & & \\
\hline Trichocerca capucina & & & & & & & & & & & & & & & & & & & & + & & & & & & \\
\hline $\begin{array}{l}\text { Trichocerca } \\
\text { cylingdrica }\end{array}$ & & & & & & & & + & & & & & & + & + & & & & & & & + & & & & \\
\hline Trichocerca elongata & & & & & & & & + & & & & & & & & & & & & & & & & & & \\
\hline Trichocerca gracilis & & & & & & & & & & & & & & & + & & & & & & & & & & & \\
\hline $\begin{array}{l}\text { Trichocerca } \\
\text { lophoessa }\end{array}$ & & & & & & & & + & & & & & & & + & & & & & & & & & & & \\
\hline Trichocerca porcsllus & & & & & & & + & & & & & & & & & & & & & & & & & & & \\
\hline Trichocerca pusilla & & & + & & & & + & + & & & & & & & & & & & & & & & & & & \\
\hline Trichocerca rattus & & & & & & & & + & & & & & & & & & & & & & & & & & & \\
\hline Trichocerca rousseleti & & + & & & & & & & & & + & & & & & & & & & & & & & & & \\
\hline Trichocerca similis & & + & & & & & & + & & + & & & & + & + & + & & & & + & & & & & & \\
\hline Trichocerca sp. 1 & & & & & & & & & & & & & & & + & & & & & & & & & & & \\
\hline
\end{tabular}




\begin{tabular}{|c|c|c|c|c|c|c|c|c|c|c|c|c|c|c|c|c|c|c|c|c|c|c|c|c|c|c|c|}
\hline Trichocerca sp. 2 & & & & & & & & & & & & & & & & & & & & + & & & & & & & \\
\hline Trichocerca sp. 3 & + & & & & & & & & & & & & & & & & & & & & & & & & & & \\
\hline Trichocerca sp. 4 & & & & & & & & & + & & & & & & & & & & & & & & & & & & \\
\hline Trichocerca weberi & + & + & & & & & & & & & & & & & & & & & & & & & & & & & \\
\hline Trichotria tetractis & + & + & & & & & & & & & & & & & & & & & & & & & & & & & \\
\hline \multicolumn{28}{|l|}{ Cladocera } \\
\hline Alona affinis & & + & & & & & & & & & & & & + & + & & + & & & & & + & + & & & & \\
\hline Alona diaphana & & + & & & & & & & & & & & & & & & & & & & & & & & & & \\
\hline Alona quadrangularis & & & & & & & & & + & & & & & & & & + & & & & & & & & & & \\
\hline Alona sp. & & & & & & & & & & & & & & & & & & & & + & & & & & & & \\
\hline Bosmina longirostris & + & + & & & & + & & + & & & + & & & + & + & + & + & & & & + & + & & & & + & + \\
\hline Bosminopsis deitersi & & & & & & & & + & & & & & & & & & & & & & & & & & & & \\
\hline $\begin{array}{l}\text { Camptocercus } \\
\text { rectirosris }\end{array}$ & & & & & & & & & & & & & & & + & & & & & & & & + & & & & \\
\hline Ceriodaphnia setosa & & & & & & & & & & & & & & & & & + & & & & & & & & & & \\
\hline Chydorus sphaericus & + & + & & + & & & + & & + & & & & & + & + & & + & & & & & & & & & & + \\
\hline Daphnia magna & & & + & + & & & & & & & & & + & + & & & & & & & + & & & + & & & \\
\hline Daphnia pulex & & & + & + & + & + & + & & & & + & + & + & + & & & + & + & + & & & & + & + & + & + & + \\
\hline Daphnia cucullata & & & & & & & + & & & & & & & + & & & + & & & & & + & & & & & + \\
\hline Daphniopsis tibetana & & + & + & + & & & & & & & & & + & + & & & + & + & + & + & + & & & & & & \\
\hline $\begin{array}{l}\text { Diaphanosoma } \\
\text { brachyurum }\end{array}$ & & & & & & & & + & & & & & & & & & & + & & & & & & & & & \\
\hline \multicolumn{2}{|l|}{$\begin{array}{l}\text { Diaphanosoma } \\
\text { leuchtenbergianum }\end{array}$} & & & & & & & & + & & & & & + & & & + & + & & & + & & & & & & \\
\hline Moina affinis & & & & & & & & + & & & & & & & & & + & & & + & + & & & + & + & + & \\
\hline Moina irrasa & & & & & & & & & & & & & & & & & & + & + & & & & & & & & \\
\hline Moina sp. & & & & & & + & & & & & & & & & + & & + & & & & & & & & & & + \\
\hline Pleuroxus trigonellus & & & & & & & & & & & & & & & + & & + & & & & & & & & & & \\
\hline Sida crystallina & & & & & & & & & & & & & + & + & + & & + & + & + & + & & & & & & & \\
\hline Simocephalus sp.1 & & & & & & & & & & & & & & & & & & & & & + & & & & & & \\
\hline Simocephalus sp. 2 & & + & & & & & & & & & & & & & & & & & & & & & & & & & \\
\hline Simocephalus vetulus & & & & & & & & & & + & & & & & & & & & & & & & & & & & \\
\hline \multicolumn{28}{|l|}{ Copepoda } \\
\hline Copepodid & + & + & + & + & + & + & + & + & + & + & & + & + & + & + & + & + & & + & + & + & + & & + & + & + & + \\
\hline
\end{tabular}

APPLIED ECOLOGY AND ENVIRONMENTAL RESEARCH 15(3): 1417-1442.

http://www.aloki.hu • ISSN 15891623 (Print) • ISSN 17850037 (Online)

DOI: http://dx.doi.org/10.15666/aeer/1503_14171442

(c) 2017, ALÖKI Kft., Budapest, Hungary 


\begin{tabular}{|c|c|c|c|c|c|c|c|c|c|c|c|c|c|c|c|c|c|c|c|c|c|c|c|c|c|}
\hline Cyclopoidea & + & + & + & + & + & + & + & & & & & & & & & & & & & & & & & & \\
\hline Tropocyclops sp. & & + & & & & & & & & & & & & + & & + & & & & & & & & & \\
\hline Eucyclops sp. & & & & & & & & & & & & & & + & & & & & & & & & & & \\
\hline $\begin{array}{l}\text { Thermocyclops } \\
\text { taihokuensis }\end{array}$ & + & + & + & + & + & + & + & + & + & + & & + & + & + & & & & + & + & & & & & & \\
\hline Nitocrella unispinosus & & + & & & & & & & & & & & & & & & & & & & & & & & \\
\hline Nauplius & + & + & + & + & & + & + & + & + & + & + & + & + & + & + & + & + & + & + & + & + & + & + & + & + \\
\hline Schmackeria forbest & & + & + & + & & & + & & & & & & + & & & + & + & & + & & & & & & \\
\hline Sinocalanus dorrii & + & + & & & & & + & & & & & & + & + & & & & & + & + & & + & & & + \\
\hline
\end{tabular}

+ Indicated the identified species. 